\title{
Cultural and Physiological Characterization of Phytophthora parasitica causing Foot Rot of Betelvine (Piper betle $\mathbf{L}$.)
}

\author{
Y.P. Prasad*, M.P. Basavarajappa, Y.S. Mahesh, R.K. Mesta, \\ D.L. Rudresh and Shankaragouda Patil
}

Harosagara Marabanahalli Post Channagiri tq Davanagere Dist. 577551, Karnataka, India *Corresponding author

\section{A B S T R A C T}

Betelvine (Piper betel L.) is an important horticulture crop of commercial values and

\section{Keywords}

Culture media,

Mycelial,

Phytophthora parasitica

\section{Article Info}

Accepted:

29 September 2017

Available Online:

10 October 2017 belongs to family Piperaceae. Betelvine is mainly grown under moist and humid shade conditions, which makes the crop more prone to many diseases. Among them foot rot caused by Phytophthora parasitica is a major one and leads to total crop loss. The mycelia of the fungus grew satisfactorily on the entire agar media used. Maximum radial growth of the pathogen was recorded on czapeck-dox agar after eight days of incubation. The optimum temperature for the mycelial growth of the fungus was observed at $20{ }^{\circ} \mathrm{C}$ followed by $25{ }^{\circ} \mathrm{C}$ and the least growth at $40{ }^{\circ} \mathrm{C}$. The maximum mycelial dry weight of the pathogen was recorded at a $\mathrm{pH} 8$ followed by $\mathrm{pH} 7$. The result with respect to effect of relative humidity showed that maximum mycelial dry weight of $P$. parasitica at $90 \%$ followed by $85 \%$ and the least wasynoticed at $60 \%$. fAmongst thencarbon csourceslls supplemented, L-asparagine, was best utilized with the highest mycelia dry weight and the least was recorded in calcium carbonate. Whereas with respect to nitrogen sources the maximum mycelial dry weight was recorded in potassium nitrate and the least in ammonium phosphate.

\section{Introduction}

Foot rot disease is an important disease in betelvine causing a yield loss of 44-86 \% and even in certain cases, entire plantations were being destroyed by the pathogen (Singh and Chand 1971). For the first time Dastur (1926) reported the occurrence of foot-rot was caused by Phytophthora parasitica.

The attack of $P$. parasitica on the roots reduces significantly the number of functional roots which leads to wilting of the plant and finally reduction in yield. Phytophthora species generally composed of tube-like (coenocytic), in contrast to the septate hyphae of fungi (Singh et al., 2006).

The fungus seems to have a poor competitive saprophytic ability and this contributes to the lack of success in isolating and growing of $P$. parasitica in an artificial medium. In order to culture the fungi in the laboratory, it is necessary to supplement suitable medium, temperature, $\mathrm{pH}$ and essential elements (carbon and nitrogen) need for growth and other metabolic processes. Hence, different media, temperature, $\mathrm{pH}$, relative humidity, carbon and nitrogen sources were tried in the 
investigation to select the best medium and other suitable condition for growth of pathogen.

\section{Material and Methods}

\section{Isolation and pure culture of the Foot rot associated pathogen}

Direct tissue isolation technique was employed for isolation Ph. parasitica on V8 media supplemented with antibiotics such as pimaricin $(100 \mu \mathrm{g} / \mathrm{ml})$, penicillin $(50 \mu \mathrm{g} / \mathrm{ml})$, polymixin B $(50 \mu \mathrm{g} / \mathrm{ml})$ and rifampicin $(10$ $\mu \mathrm{g} / \mathrm{ml})$ as described by Drenth and Sendall (2001). Stem/collar portion showing actively progressing lesions were used for isolation of pathogen. The infected stem portions were washed thoroughly in tap water. The samples were then cut into small pieces having infected and healthy portion. Surface sterilised with 0.1 per cent sodium hypochlorite solution for 60 seconds and then washed thoroughly for three to four times in sterile distilled water under aseptic condition. The samples were then placed aseptically in sterile Petri plates containing medium and incubated at $25 \pm 2{ }^{\circ} \mathrm{C}$ for $8-10$ days. Pure cultures of the fungi were obtained by hyphal tip isolation method.

Effect of different solid media on the growth of Phytophthora parasitica

Growth characters of Phytophthora parasitica on ten different media viz., Potato dextrose agar, V-8 Juice agar, Oat meal agar, Malt extract agar, Corn meal agar, Carrot agar, Sabouraud's agar, Richards's agar, Czapek's Dox agar and Glucose aspergine agar. All the media were sterilized in autoclaved. To carry out the study, $15 \mathrm{ml}$ of each of the medium was poured in $90 \mathrm{~mm}$ Petri plates. Such Petri plates were inoculated with $5 \mathrm{~mm}$ disc cut from periphery of actively growing cultures and incubated at $23 \pm 1^{\circ} \mathrm{C}$. Each treatment was replicated thrice. Observations like colony size, mycelial color and substrate color, margin of the colony and topography of the colony were recorded at eight days after inoculation. The effect of media on radial growth was analyzed statistically. The best performing media was used in further experiments.

\section{Studies on growth rate of isolated pathogen in liquid media}

From the previous experiment, the solid media that support the good growth of the pathogen was selected for growth studies, but as broth. Twenty five $\mathrm{ml}$ of respective liquid media was pipetted into each of the $100 \mathrm{ml}$ conical flasks. The broths were subjected to Autoclaving. The mycelial bits from the pure culture were inoculated to the conical flask containing the broth and incubated up to 20 days at $23 \pm 1^{\circ} \mathrm{C}$. A set of three flasks were harvested at every 2 days interval to know the growth curve. Cultures were filtered through Whatman No. 1 filter paper. The mycelial mat on the filter paper was thoroughly washed with distilled water to leach out any salts associated with the mycelium. Subsequently, the filter papers along with mycelial mat were dried in hot air oven at a temperature of $45 \pm 5$ ${ }^{\circ} \mathrm{C}$ and dry mycelial weight was recorded.

\section{Effect of temperature on growth of Phytophthora parasitica}

Temperature range i.e. 15, 20, 25, 30, 35 and $40{ }^{\circ} \mathrm{C}$ were tried to see the effect on the growth of the pathogen. $25 \mathrm{ml}$ of sterilized medium was dispensed in $100 \mathrm{ml}$ conical flask and inoculated aseptically with $5 \mathrm{~mm}$ disc of the pathogens from a seven days old culture. Conical flasks were incubated at different temperature and each treatment was replicated four times. At the end of eight days of incubation, the mycelia of the pathogens were harvested and dried in hot air oven as 
explained earlier. Finally dried mycelium weight was recorded.

\section{Effect of $\mathrm{pH}$ on the growth of pathogen}

Different media $\mathrm{pH}$ of $4.0,5.0,6.0,7.0,8.0$ and 9.0 were used. The culture was inoculated to each of $100 \mathrm{ml}$ flask containing $25 \mathrm{ml}$ of basal medium. Inoculated flasks were incubated at $23 \pm 1{ }^{\circ} \mathrm{C}$ for eight days, four replications were maintained for each treatment. Dry mycelial weight of the fungus was recorded.

\section{Effect of relative humidity on the growth of pathogen}

Different levels of relative humidity viz., 60, $65,70,75,80,85$ and 90 per cent were tried against the growth of pathogen by dissolving $38,36,33,30,27,23$ and 18 per cent concentrated sulphuric acid $\left(\mathrm{H}_{2} \mathrm{SO}_{4}\right)$ respectively in the desiccators containing distilled water. Twenty five $\mathrm{ml}$ of sterilized broth medium was dispensed in $100 \mathrm{ml}$ conical flask and inoculated aseptically with 5 $\mathrm{mm}$ disc of the pathogen from a seven days old culture. The conical flasks were kept in the desiccators and were incubated at ambient temperature. Three replications were maintained for each treatment. At the end of eight days of incubation, the mycelia were harvested as explained earlier and data were recorded.

\section{Effect of different carbon sources on the growth of Phytophthora parasitica}

The quantity of each carbon compound to be added was determined on the basis of their molecular weight, so as to provide equivalent amount of carbon as that of carbon compound present in the basal medium. The carbon compounds used were glucose, fructose, xylose, sodium carbonate, L-asparagine, calcium carbonate and sucrose. $25 \mathrm{ml}$ of each media were poured into $100 \mathrm{ml}$ flasks and autoclaved. Each treatment was replicated thrice. All the flasks were aseptically inoculated with $5 \mathrm{~mm}$ mycelial disc of seven days old culture and incubated at $23 \pm 1{ }^{\circ} \mathrm{C}$ for eight days. At the end of eight days of incubation, the mycelia were harvested as explained earlier and recorded the dry mycelial weight.

\section{Effect of different nitrogen sources on the growth of Phytophthora parasitica}

The quantity of each nitrogen compound to be added was determined on the basis of their molecular weight, so as to provide equivalent amount of nitrogen as that of nitrogen compound present in the basal medium. The nitrogen compounds used were ammonium phosphate, calcium nitrate, L-glutamic acid, L-arginine, potassium nitrate, ammonium sulphate and sodium nitrate. Twenty five $\mathrm{ml}$ of each media were poured into $100 \mathrm{ml}$ flasks and autoclaved at $1.05 \mathrm{~kg} \mathrm{~cm}^{-2}$ pressure with a temperature of $121.6{ }^{\circ} \mathrm{C}$ for $15 \mathrm{~min}$. Each of the treatment was replicated thrice. All the flasks were aseptically inoculated with $5 \mathrm{~mm}$ mycelial disc of seven days old culture and incubated at $23 \pm 1{ }^{\circ} \mathrm{C}$ for eight days. At the end of eight days of incubation, the mycelia were harvested as explained earlier and recorded dry mycelial weight.

\section{Statistical analysis}

The results of experiments were analyzed by using the methods as described by Fischer and Yates (1963).

\section{Result and Discussion}

In the present study culture of $P$. parasitica showed moderately compact, sparse to densely raised colonies, daisy, porcelain to white mycelial growth with uniform to wavy margin when grown on different medium (Table 1 and Plate 1). Morphometric studies revealed that, the size of sporangium varies 
from 10.80-32.38 $\mu \mathrm{m} \times$ 7.14-24.04 $\mu \mathrm{m}$ arising from the sporangiophore $(19.23 \mu \mathrm{m}$ to $46.45 \mu \mathrm{m}$ in length). Aerial hyphae were long, sparingly branched $(6.76 \mu \mathrm{m}$ to $68.52 \mu \mathrm{m}$ distance between the branches), uniform in diameter $(2.90 \mu \mathrm{m})$. Sporangial shapes were pear, ovoid and spherical in different isolates and they were papillate. On the basis of study of cultural and morphometric characteristics, it was concluded that the species closely resembled $P$. parasitica as characterised by Ribeiro (1978).

Among 10 solid media evaluated against $P$. parasitica, the maximum growth of fungus was observed in czapeck dox agar (86.50 $\mathrm{mm}$ ) at eight days of incubation followed by Sabouraud's agar $(85.30 \mathrm{~mm})$. Whereas the minimum growth of the pathogen was recorded on malt extract agar with a colony diameter of $41.70 \mathrm{~mm}$ (Table 1 and Plate 1). These results are in contradiction to findings of Rao et al., (1962) who recorded the maximum growth of $P$. parasitica Dast. var. macrospora Ashby on rice meal agar $(85 \mathrm{~mm})$ followed by oat meal $(76.55 \mathrm{~mm})$ and minimum mycelium growth in czapek's dox agar $(10 \mathrm{~mm})$. Whereas Padmaja, et al., (2015) obtained the best growth of $P$. colocasiae on carrot agar $(86 \mathrm{~mm})$, followed by papaya sucrose agar $(80.6 \mathrm{~mm})$ and less growth of the pathogen was recorded on PDA (22 mm).

Growth phase study was conducted to know the progress of pathogen growth on liquid media over a time. For this experiment solid media that supported the good growth of $P$. parasitica was selected as liquid media to record the dry mycelial weight of the pathogen. Czapeck dox agar that supported the good growth of the pathogen, so this medium selected to assess the dry mycelial weight of the pathogen. Maximum dry weight $(307.13 \mathrm{mg}$ ) of $P$. parasitica was recorded at $8^{\text {th }}$ day after incubation at $23 \pm 1{ }^{\circ} \mathrm{C}$ (Table 2 ). Phytophthora parasitica grow at wide range of temperature ranging from $15-40{ }^{\circ} \mathrm{C}$. But the maximum mean dry mycelium weight (330.38 mg) was observed at $20{ }^{\circ} \mathrm{C}$ after eight days of incubation, which is considered to be optimum temperature for the better growth of the pathogen, followed by $25{ }^{\circ} \mathrm{C}(250.05 \mathrm{mg})$ (Table 3 and Plate 2). The least growth of the pathogen was observed at $40{ }^{\circ} \mathrm{C}(102.98 \mathrm{mg})$. These results were in conformity with the findings of Mounde et al., (2012) who reported that the colony diameter of $55 \mathrm{~mm}$ and $0 \mathrm{~mm}$ for $P$. citrophthora was observed at $24{ }^{\circ} \mathrm{C}$ and $35{ }^{\circ} \mathrm{C}$ respectively. Mbong et al., (2015) reported that optimum temperature for maximum growth of pathogen was $24{ }^{\circ} \mathrm{C}$ (72.30 mm).

Maximum growth of the $P$. parasitica was recorded at $\mathrm{pH} 8(377.00 \mathrm{mg})$ which was significantly superior to all other $\mathrm{pH}$ range followed by $\mathrm{pH} 7(243.38 \mathrm{mg})$ and least growth of the fungus was observed at $\mathrm{pH} 4.0$ (136.13 mg) (Table 4 and Plate 3).

The results of the present study are in accordance with the earlier findings of Gaston et al., (2014) who observed that the $\mathrm{pH}$ ranging from 6 to 9 support better radial growth of $P$. colocasiae. Mbong et al., (2015) reported that among the different $\mathrm{pH}$ levels, ranging from 6 to 8 supported the good growth of the $P$. colocasiae but the maximum growth was observed at $\mathrm{pH} 7(85.30 \mathrm{~mm})$ and least growth was recorded at $\mathrm{pH} 4(66.00$ $\mathrm{mm})$.

Better growth of $P$. parasitica was observed at 90 per cent RH with $177.40 \mathrm{mg}$ of mycelial dry weight followed by 85 per cent (166.13 $\mathrm{mg}$ ) and least growth was at 60 per cent (119.23 mg) (Table 5 and Plate 4). These results were in line with the findings of Naik et al., (2016) that $R$. solani flourished well at 80 and 90 per cent RH with colony diameter of $89.27 \mathrm{~mm}$ and $89.20 \mathrm{~mm}$ and least growth of the pathogen was noticed at 60 per cent $(80.31 \mathrm{~mm})$. 
Table.1 Radial growth and Morphological characteristics of Phytophthora parasitica on different media

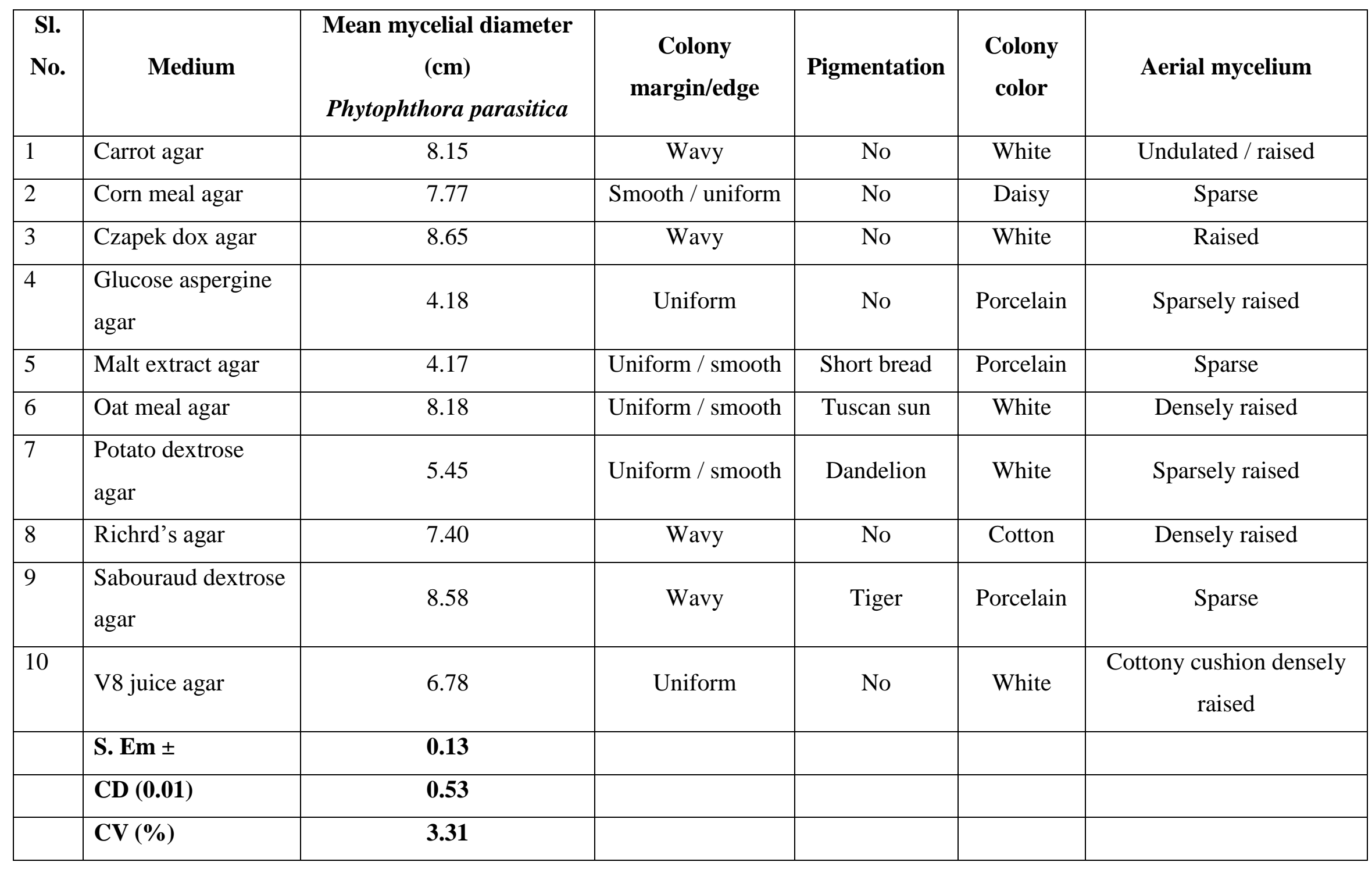


Table.2 Growth rate of Phytophthora parasitica on czapek dox broth

\begin{tabular}{|c|c|c|}
\hline Sl. No. & Days after incubation & Mean mycelial dry weight (mg) \\
\hline 1 & 02 & 81.57 \\
\hline 2 & 04 & 90.27 \\
\hline 3 & 06 & 96.83 \\
\hline 4 & 08 & 307.13 \\
\hline 5 & 10 & 173.25 \\
\hline 6 & 12 & 153.80 \\
\hline 7 & 14 & 130.00 \\
\hline 8 & 16 & 201.30 \\
\hline 9 & 18 & 189.33 \\
\hline 10 & 20 & 264.80 \\
\hline & S. $\mathbf{E m} \pm$ & $\mathbf{3 . 1 8}$ \\
\hline & $\mathbf{C D}(\mathbf{0 . 0 1})$ & $\mathbf{1 2 . 8 0}$ \\
\hline & $\mathbf{C V}(\boldsymbol{\%})$ & $\mathbf{3 . 2 6}$ \\
\hline
\end{tabular}

Table.3 Effect of different temperature on the growth of Phytophthora parasitica

\begin{tabular}{|c|c|c|}
\hline Sl. No. & Temperature $\left({ }^{\mathbf{0}} \mathbf{C}\right)$ & Mean mycelial dry weight (mg) \\
\hline 1 & 15 & 227.78 \\
\hline 2 & 20 & 330.38 \\
\hline 3 & 25 & 250.05 \\
\hline 4 & 30 & 156.88 \\
\hline 5 & 35 & 142.65 \\
\hline 6 & 40 & 102.98 \\
\hline & S. $\mathbf{E m} \pm$ & $\mathbf{2 . 3 7}$ \\
\hline & $\mathbf{C D}(\mathbf{0 . 0 1})$ & $\mathbf{9 . 6 5}$ \\
\hline & $\mathbf{C V}(\boldsymbol{\%})$ & $\mathbf{2 . 3 4}$ \\
\hline
\end{tabular}

Table.4 Effect of different $\mathrm{pH}$ levels on the growth of Phytophthora parasitica

\begin{tabular}{|c|c|c|}
\hline Sl. No. & pH levels & Mean mycelial dry weight $(\mathbf{m g})$ \\
\hline 1 & 4 & 136.13 \\
\hline 2 & 5 & 203.13 \\
\hline 3 & 6 & 205.23 \\
\hline 4 & 7 & 243.38 \\
\hline 5 & 8 & 377.00 \\
\hline 6 & 9 & 219.35 \\
\hline & S. $\mathbf{E m} \pm$ & $\mathbf{1 . 9 2}$ \\
\hline & CD $(\mathbf{0 . 0 1})$ & $\mathbf{5 . 2 1}$ \\
\hline & CV $(\boldsymbol{\%})$ & $\mathbf{1 . 1 1}$ \\
\hline
\end{tabular}


Table.5 Effect of relative humidity on growth of Phytophthora parasitica

\begin{tabular}{|c|c|c|}
\hline Sl. No. & Relative humidity (\%) & Mean mycelial dry weight (mg) \\
\hline 1 & 60 & 119.23 \\
\hline 2 & 65 & 128.50 \\
\hline 3 & 70 & 138.83 \\
\hline 4 & 75 & 144.73 \\
\hline 5 & 80 & 149.50 \\
\hline 6 & 85 & 166.13 \\
\hline 7 & 90 & 177.40 \\
\hline & S. Em \pm & $\mathbf{2 . 1 8}$ \\
\hline & CD $(\mathbf{0 . 0 1})$ & $\mathbf{9 . 1 9}$ \\
\hline & CV (\%) & $\mathbf{2 . 5 8}$ \\
\hline
\end{tabular}

Table.6 Effect of different carbon sources on growth of Phytophthora parasitica

\begin{tabular}{|c|l|c|}
\hline Sl. No. & \multicolumn{1}{|c|}{ Carbon source } & Mean mycelial dry weight (mg) \\
\hline 1 & Calcium carbonate & 0.00 \\
\hline 2 & Fructose & 318.73 \\
\hline 3 & Glucose & 339.13 \\
\hline 4 & L- asparagine & 481.70 \\
\hline 5 & Sodium carbonate & 442.03 \\
\hline 6 & Sucrose & 396.10 \\
\hline 7 & Xylose & 286.80 \\
\hline & S. Em \pm & $\mathbf{4 . 6 7}$ \\
\hline & $\mathbf{C D}(\mathbf{0 . 0 1})$ & $\mathbf{1 9 . 6 7}$ \\
\hline & $\mathbf{C V}(\mathbf{\%})$ & $\mathbf{2 . 5 0}$ \\
\hline
\end{tabular}

Table.7 Effect of different nitrogen sources on growth of Phytophthora parasitica

\begin{tabular}{|c|l|c|}
\hline Sl. No. & \multicolumn{1}{|c|}{ Nitrogen source } & Mean mycelial dry weight (mg) \\
\hline 1 & Ammonium phosphate & 132.27 \\
\hline 2 & Ammonium Sulphate & 206.07 \\
\hline 3 & Calcium nitrate & 282.70 \\
\hline 4 & L- arginine & 165.87 \\
\hline 5 & L- glutamic acid & 169.03 \\
\hline 6 & Potassium nitrate & 349.17 \\
\hline 7 & Sodium nitrate & 199.07 \\
\hline & S. Em \pm & $\mathbf{2 . 2 4}$ \\
\hline & CD $(\mathbf{0 . 0 1})$ & $\mathbf{9 . 4 3}$ \\
\hline & CV $(\boldsymbol{\%})$ & $\mathbf{1 . 8 0}$ \\
\hline
\end{tabular}


Plate.1 Growth of Phytophthora parasitica on different media

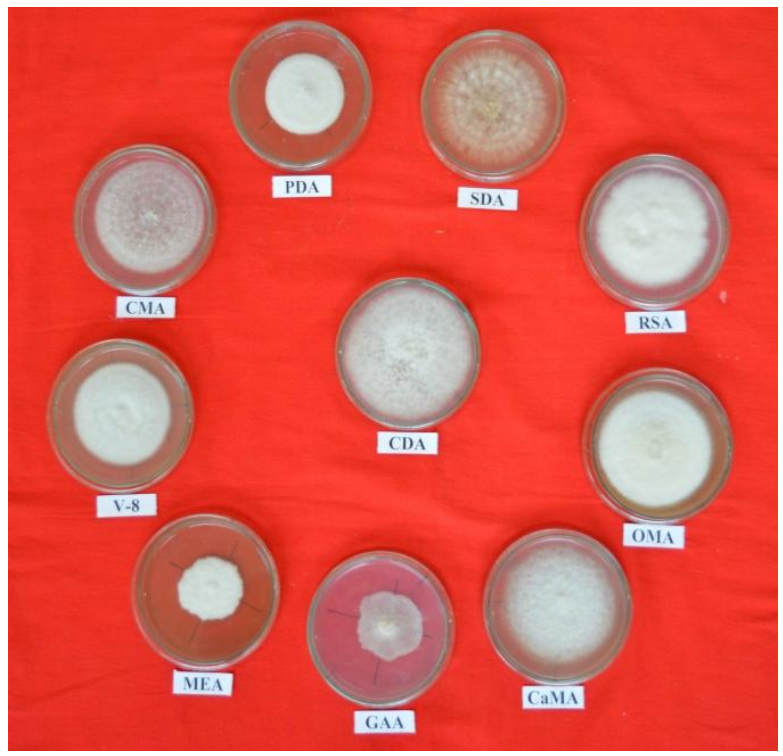

A. Mycelial growth

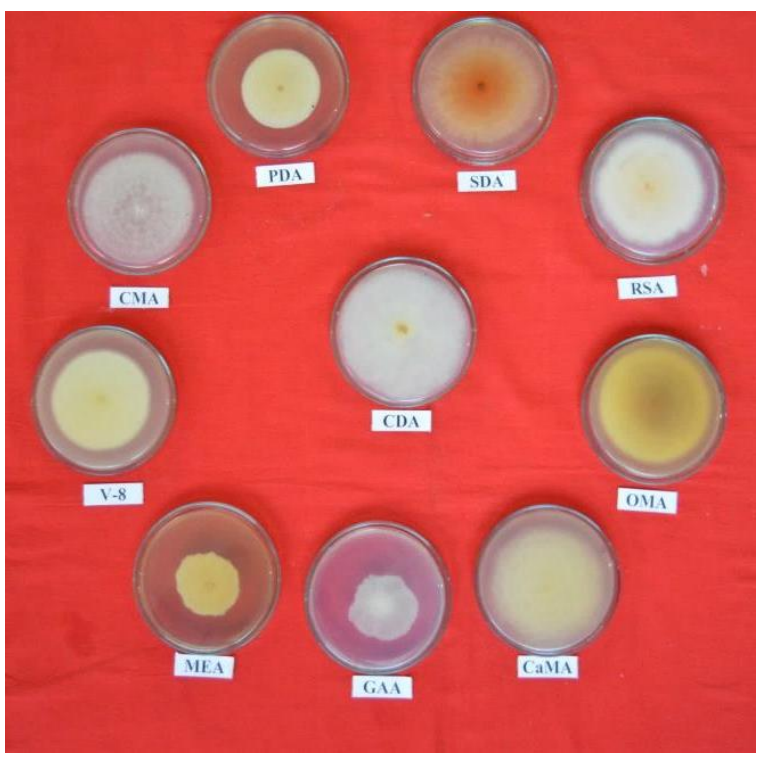

B. Pigmentation

Plate.2 Growth of Phytophthora parasitica at different temperature

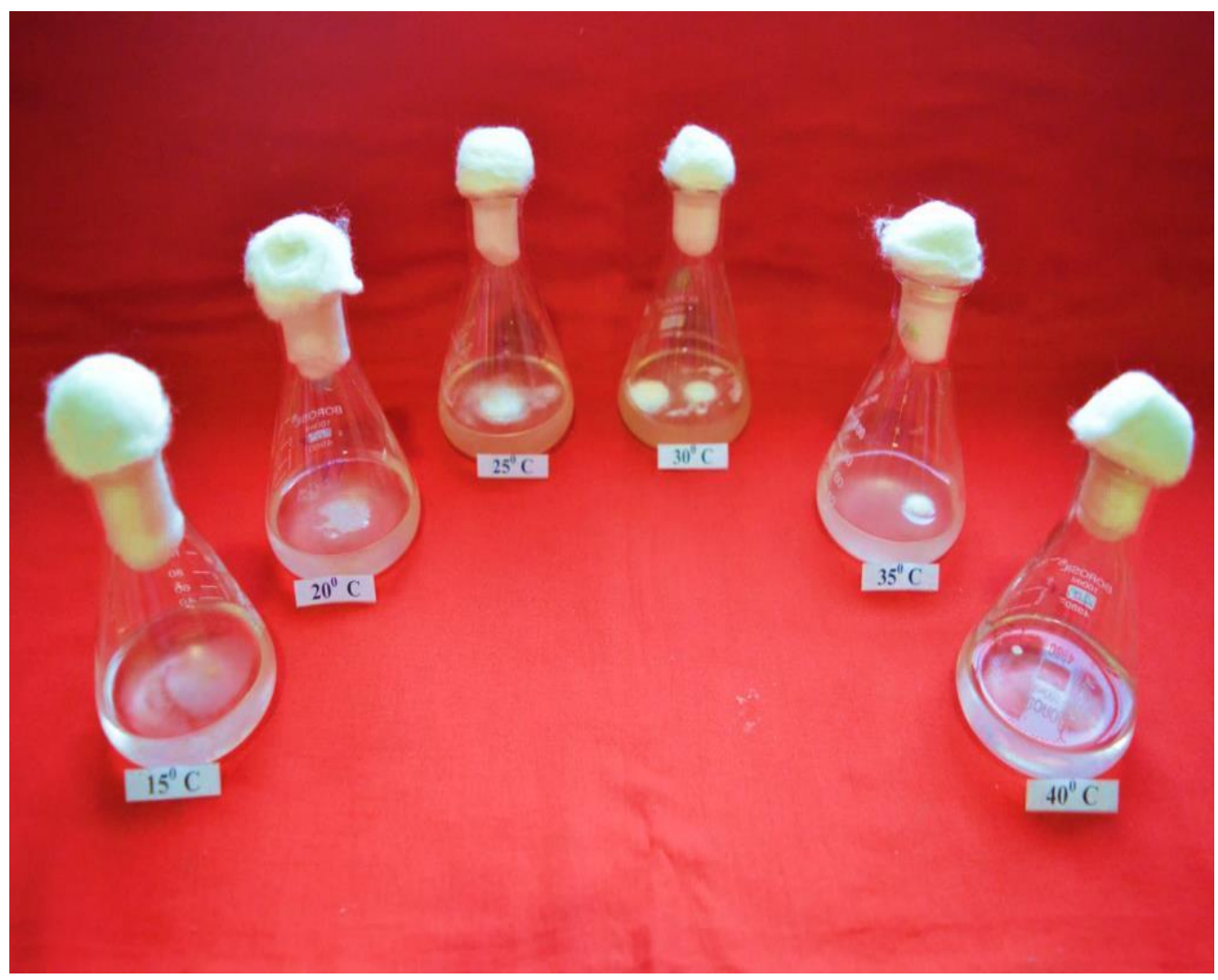


Plate.3 Growth of Phytophthora parasitica at different hydrogen ion concentration ( $\mathrm{pH}$ )

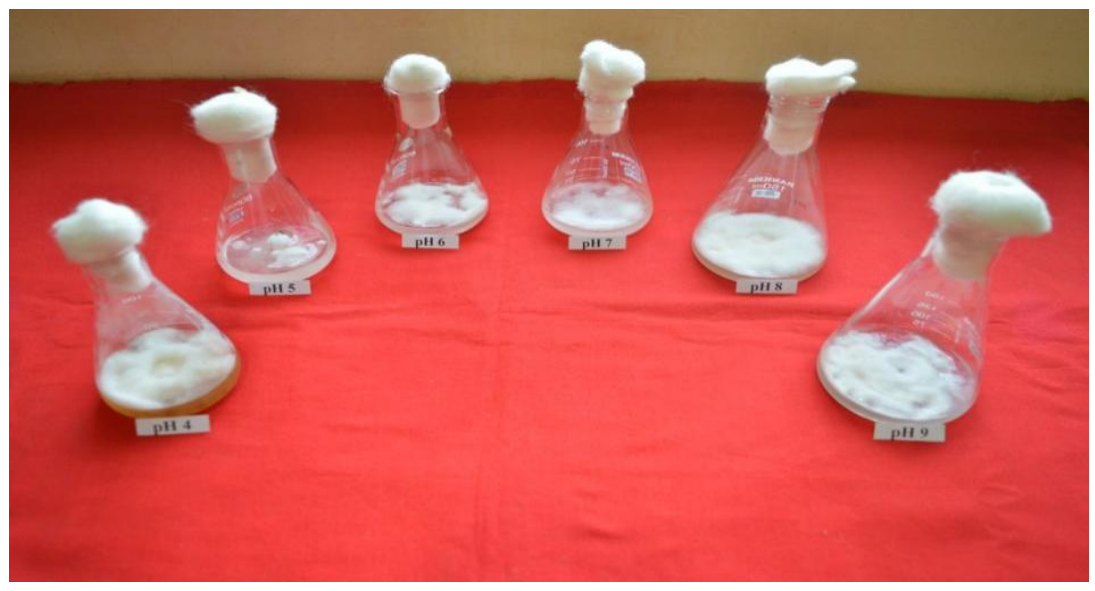

Plate.4 Growth of Phytophthora parasitica at different levels of relative humidity (RH)

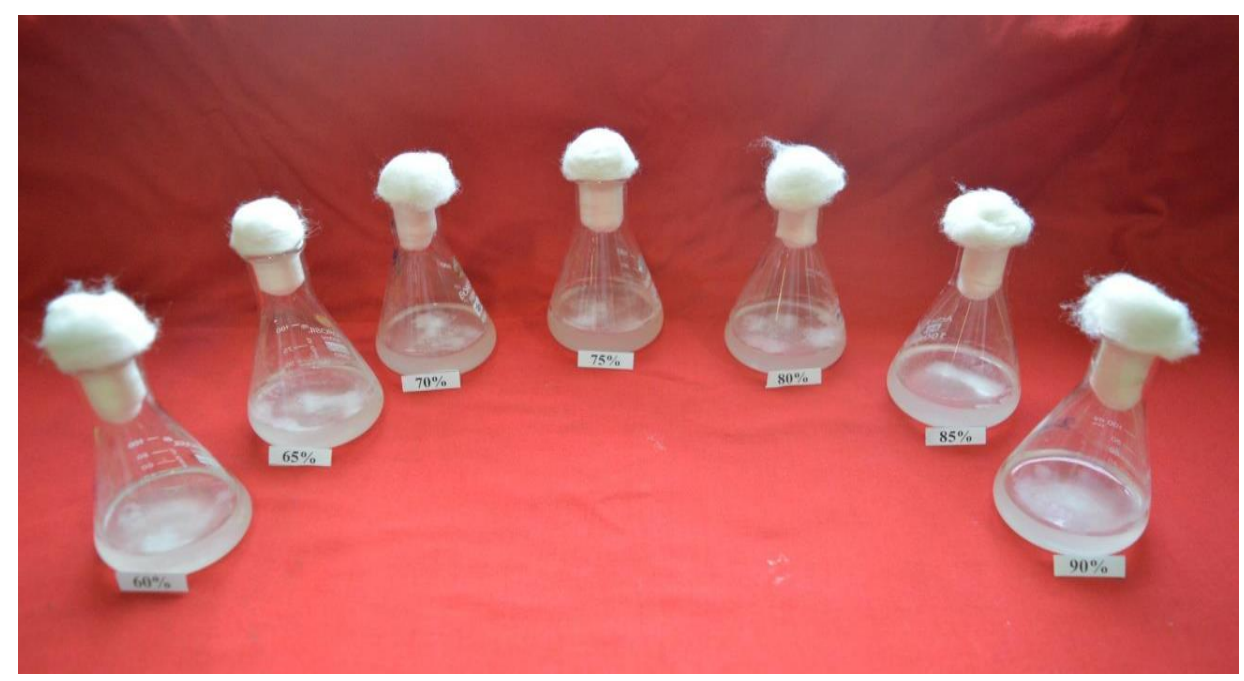

Plate.5 Growth of Phytophthora parasitica on different carbon sources

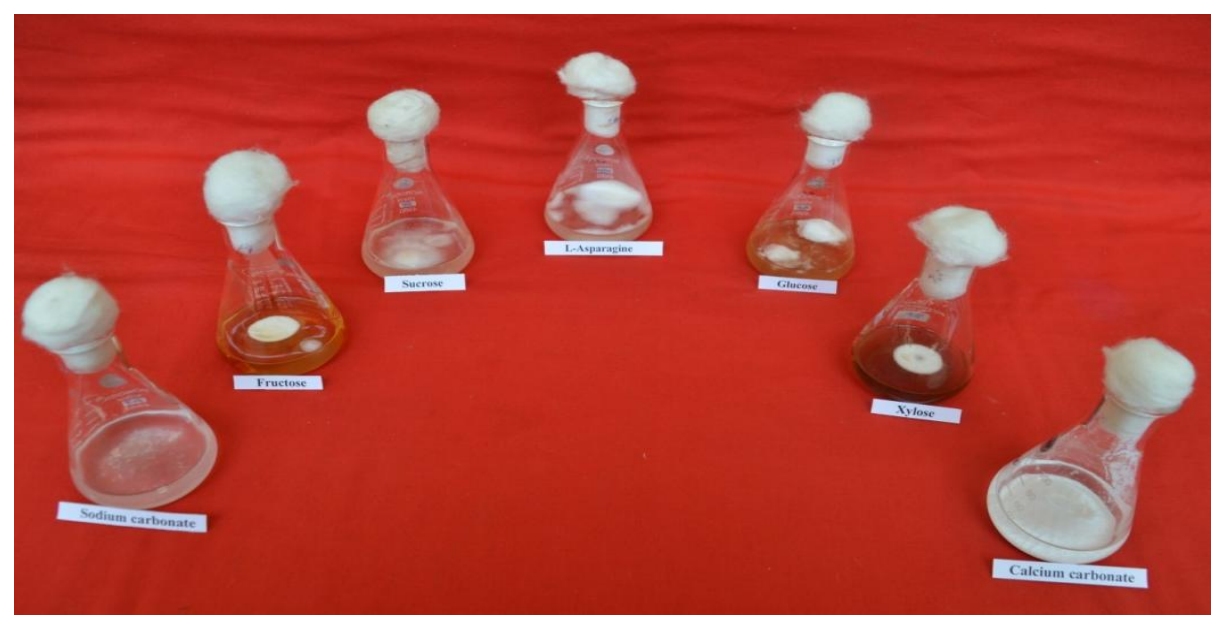




\section{Plate.6 Growth of Phytophthora parasitica on different nitrogen sources}

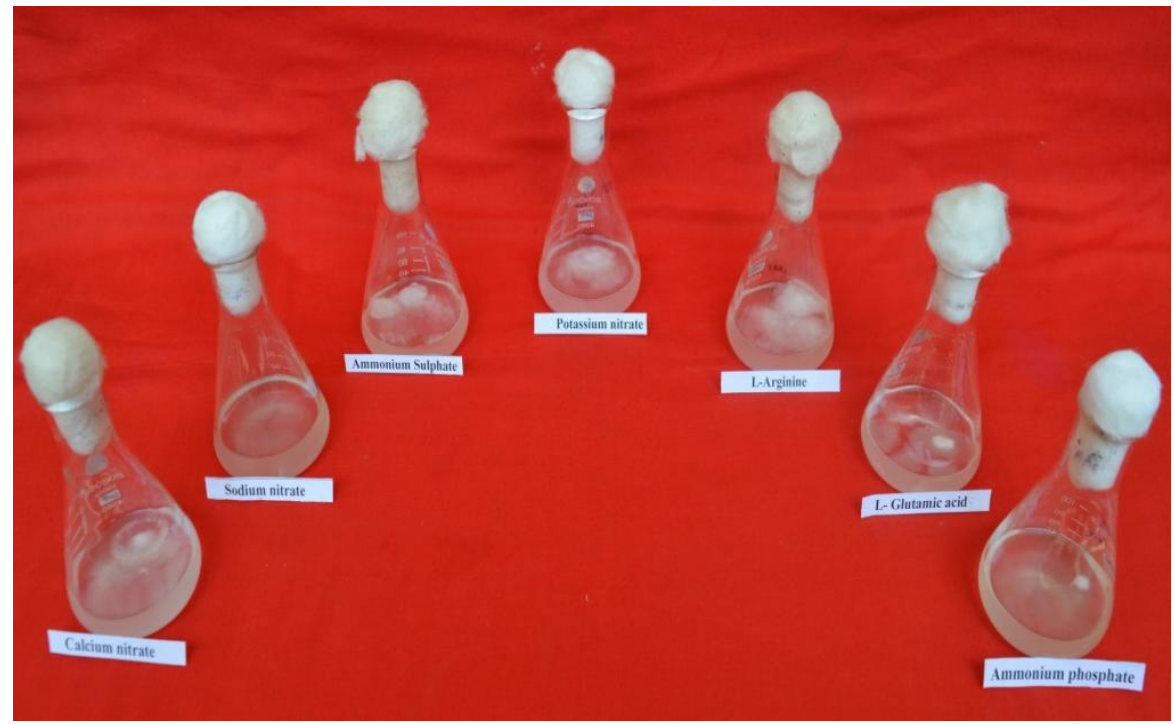

Among different carbon sources evaluated, better growth of Phytophthora parasitica was recorded on L-asparagine (481.70 $\mathrm{mg})$, followed by sodium carbonate $(442.03 \mathrm{mg})$ and no growth was recorded in calcium carbonate $\left(\begin{array}{llll}0.00 & \mathrm{mg}\end{array}\right)$ eight days after incubation (Table 6 and Plate 5). This result was contradictory with the findings of Shepherd and Pratt (1973) who found out of 37 carbon sources on growth of $P$. nicotianae var. nicotianae. The result revealed that maximum dry weight of mycelium was supported by sucrose $(42.70 \mathrm{mg})$ followed by raffinose $(42.2 \mathrm{mg})$, melezitose $(42.00 \mathrm{mg})$, amylose $(40.50 \mathrm{mg})$ and maltose $(36.80 \mathrm{mg})$. Whereas, the least growth of pathogen was recorded in cellulose $(1.5 \mathrm{mg})$.

Among seven nitrogen sources tested in the present investigation, maximum mean dry mycelial weight of $P$. parasitica was observed in potassium nitrate $(349.17 \mathrm{mg})$ followed by calcium nitrate $(282.70 \mathrm{mg})$. Whereas, least mean dry mycelial weight was recorded in ammonium phosphate $(132.27 \mathrm{mg})$ after eight days of incubation (Table 7 and Plate 6). These results are in contradiction to findings of Peries et al., (1979) who reported that DL- asparagine (89 mg dry mycelium weight), DL- alanine $(100 \mathrm{mg}), \mathrm{L}(+)$ glutamic acid $(83$ $\mathrm{mg})$, L (-) histidine $(85 \mathrm{mg})$, L (-) proline $(111 \mathrm{mg})$ and $\mathrm{L}(-)$ serine $(89 \mathrm{mg})$ were the best nitrogen sources for the growth of the $P$. meadii. But for $P$. palmivora DL- asparagine (90 mg), L (+) aspartic acid (92 mg), L (-) arginine $(95 \mathrm{mg}$ ) and $\mathrm{L} \mathrm{(-)}$ proline $(96 \mathrm{mg}$ of dry mycelium weight) supported the growth of the pathogen. These findings revealed that the nitrogen requirement vary from species to species.

\section{References}

Dastur, J. F., 1926. Report, Department of AgriculJure, C. P. and Berar 19241925.: 23-46.

Drenth, A., and Sendall, B., 2001. Practical guide to detection and identification of Phytophthora CRC for Tropical Plant Protection Australia: pp.1-42.

Fisher, R.R., and Yates, F., 1963. Statistical tables for biological, agricultural and medical research. Sixth edition, Oliver and Boyd, Tweedale Court, Edinberg, pp. 747-777.

Gaston, T. N., Appolinaire, L. J., Jean, M. C. 
and Ajong, F. D., 2014. Effect of different $\mathrm{pH}$ and temperature levels on in vitro growth and sporulation of Phytophthora colocasiae, taro leaf blight pathogen. Int. J. Agron. And Agric. Res., 4 (4): 202-206.

Mbong, G. A., Fokunang, C. N., Manju, E. B., Njukeng, A. P., Tembe-Fokunang, E. A. and Hanna, R. 2015. Mycelia Growth and Sporulation of Phytophthora colocasiae isolates under selected conditions. American J. Expt. Agric., 8 (4): 193-201.

Mounde, L. G., Ateka, E. M., Kihurani, A. W. and Wasilwa, L., 2012. Morphological characterization and identification of Phytophthora species causing citrus gummosis in kenya. African J. Food, Agric., Nut. And Devp, 12 (7): 70727087.

Naik, T. S., Somasekhara, Y. M., Raja and Rao T. G., 2016. Effect of Temperature and relative humidity on radial growth and Sclerotial Production of Rhizoctonia solani caused Root rot in French bean. Adv. Life Sci., 5 (3): 869872.

Padmaja, G., Devi, G. U., Mahalakshmi, B. K. and Sridevi, D., 2015. Evaluation of culture media for mycelial and sporangial production of Phytophtora colocasiae, Int. J. App. Bio. And Phar.
Tech., 6 (1): 144-147.

Peries, O.S., Liyanage, A. S., and Dantanarayana, D. M., 1979. A comparative study of the nutrition of Phytophthora meadii \& P. palmivora. J. Rubb. Res. Inst. Sri Lanka, 56: 1-8.

Rao, G.V., Desai, M. K. and Kulkarni, N. B., 1962. Cultural and physiological studies of Phytophthora parasitica Dast. Var. macrospora Ashby, causing fruit rot of Anonasquamosa L. Mycopathologia ET Mycologia Applicata., 28 (3): 249-256.

Ribeiro, O.K., 1978. A source Book of the Genus Phytophthora, Vaduz, J. Cramer, Germany.

Shepherd, C.J., and Pratt, B. H., 1973. Characterization of an isolate of Phytophthora nicotianae var. nicotianae from North queensland. Aust. J. bioI. Sci., 26: 1087-94.

Singh, B.P., and Chand, I. N., 1971. Studies on the diseases of pan (Piper betle L.) due to Phytophthora parasitica Dastur in Jabalpur (Madhya Pradesh). Sci. Cult., 37: 209-10.

Singh, D., Guaf, J., Okpul, T., Wiles, G. and Hunter, D., 2006. Taro (Colocasia esculenta) variety release recommendations for Papua New Guinea based on multi-location trials. N. Z. J. Crop Horticult. Sci., 34: 163171.

\section{How to cite this article:}

Prasad, Y.P., M.P. Basavarajappa, Y.S. Mahesh, R.K. Mesta, D.L. Rudresh and Shankaragouda Patil. 2017. Cultural and Physiological Characterization of Phytophthora parasitica Associated with Foot Rot of Betelvine (Piper betle L.). Int.J.Curr.Microbiol.App.Sci. 6(10): 5023-5034. doi: https://doi.org/10.20546/ijcmas.2017.610.476 